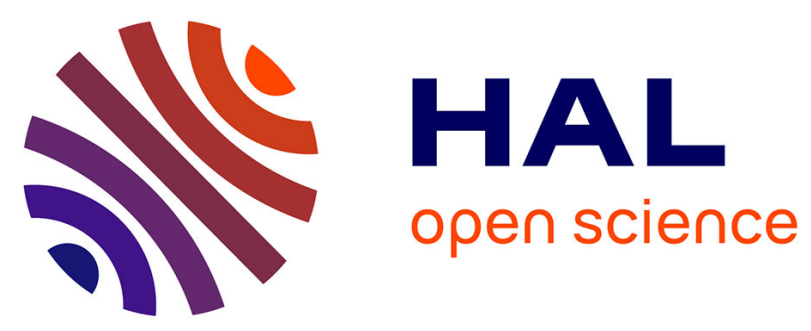

\title{
Seismic anisotropy and shear-wave splitting in lower-crustal and upper-mantle rocks from the Ivrea Zone: experimental and calculated data
}

Guilhem Barruol, Hartmut Kern

\section{- To cite this version:}

Guilhem Barruol, Hartmut Kern. Seismic anisotropy and shear-wave splitting in lower-crustal and upper-mantle rocks from the Ivrea Zone: experimental and calculated data. Physics of the Earth and Planetary Interiors, 1996, 95, pp.175 - 194. 10.1016/0031-9201(95)03124-3 . hal-01389712

\section{HAL Id: hal-01389712 \\ https://hal.univ-reunion.fr/hal-01389712}

Submitted on 29 Oct 2016

HAL is a multi-disciplinary open access archive for the deposit and dissemination of scientific research documents, whether they are published or not. The documents may come from teaching and research institutions in France or abroad, or from public or private research centers.
L'archive ouverte pluridisciplinaire HAL, est destinée au dépôt et à la diffusion de documents scientifiques de niveau recherche, publiés ou non, émanant des établissements d'enseignement et de recherche français ou étrangers, des laboratoires publics ou privés. 


\title{
Seismic anisotropy and shear-wave splitting in lower-crustal and upper-mantle rocks from the Ivrea Zone-experimental and calculated data
}

\author{
Guilhem Barruol ${ }^{\mathrm{a}, *}$, Hartmut Kern ${ }^{\mathrm{b}}$ \\ a Laboratoire de Tectonophysique, URA CNRS 1764. Université Montpellier Il, 34095 Montpellier, France \\ ${ }^{\mathrm{b}}$ Mineralogisch-Petrographisches Institut. Olshausenstr. 40. D24098 Kiel. Germany
}

Received 27 October 1994; accepted 31 August 1995

\begin{abstract}
To quantify the relationships between anisotropy. S-wave splitting and tectonics, we determined the seismic properties of lower-crustal and upper-mantle rocks outcropping in the Ivrea Zone (Northem Italy). We obtained P- and S-wave seismic velocities by laboratory direct velocity measurements and/or by calculations based on the modal compositions of the rocks, the lattice preferred orientations (LPOs), and the single crystal stiffness coefficients. Measured P- and S-wave velocities $\left(6.0-7.5 \mathrm{~km} \mathrm{~s}^{-1}\right.$ and $\left.3.6-4.2 \mathrm{~km} \mathrm{~s}^{-1}\right)$ are typical of the lower crust. The P-wave anisotropy is in the range $0-10 \%$. Shear-wave birefringence is in the range $0.0-0.6 \mathrm{~km} \mathrm{~s}^{-1}$, with typical values between 0.0 and $0.2 \mathrm{~km} \mathrm{~s}^{-1}$. In many cases, the birefringence is clearly related to fabric elements (foliation, lineation). Mafic rocks such as anorthosite or pyroxene-bearing gabbros exhibit low P-wave anisotropies $(<5 \%)$ and low shear-wave birefringences (less than $0.1 \mathrm{~km} \mathrm{~s}^{-1}$ ). In contrast, the seismic properties of felsic rocks such as biotite-bearing gneisses and mafic rocks such as amphibolites display high $V_{\mathrm{P}}$ anisotropy $(10 \%)$ and strong birefringence $\left(0.3 \mathrm{~km} \mathrm{~s}^{-1}\right)$. Biotite and amphibole preferred orientations clearly control seismic anisotropy and particularly shear-wave splitting. In these rocks, maximum splitting is observed in directions parallel to the foliation with the fast split shear wave polarized parallel to the foliation plane. To have an overview of the seismic properties of this lower-crustal section at a broader scale, we calculated from our data the anisotropic seismic properties of several hypothetical samples that are perhaps more representative of the regional anisotropy than each sample individually. For instance, the average lower-crustal sample displays an anisotropy of $5.5 \%$ for $\mathrm{P}$ waves and a birefringence around $0.14 \mathrm{~km} \mathrm{~s}^{-1}$ for $\mathrm{S}$ waves propagating parallel to the foliation. We observe little splitting for waves propagating at high angle to the foliation.
\end{abstract}

\section{Introduction}

The Ivrea Zone, northem Italy, is considered to be one of the best examples of an exposed lower-crustal

\footnotetext{
Corresponding author.
}

terrane. It provides a unique opportunity for geophysicists and petrophysicists to observe and study a large area (several tens of square kilometres) of rocks formed or metamorphosed at lower-crustal conditions. This zone has been studied by several workers as a potentially good example of layered lower crust (e.g. Hurich and Smithson, 1987; Hol- 
liger and Levander, 1994). Fountain (1976) and Burke and Fountain (1990) made laboratory seismic measurements on Ivrea Zone rocks. In these studies, however, no birefringence measurements were made. Burlini and Fountain (1993) measured shear-wave splitting in Ivrea Zone samples, but their work was focused on mid-crustal metapelite of the 'Serie dei Laghi'. In this study, we concentrate on the shearwave velocities and particularly on birefringences of rocks from the westernmost part of the Ivrea Zone, which represents the former, pre-tilting, lowermost level of the crust and possibly the uppermost mantle.

The investigation of shear-wave splitting (SWS) in lower-crustal rocks is important for two closely related reasons. First, quantification of possible crustal contributions to teleseismic SWS may lead to a more precise information of actual upper-mantle delay times and may therefore better constrain the location and magnitude of anisotropy in the Earth. Splitting of teleseismic S waves (SKS and SKKS waves, for instance) has been generally considered to occur in the upper mantle (e.g. Silver and Chan, 1991; Bormann et al., 1992), but particularly in continental regions, one cannot rule out that the crust may contribute to the total splitting. Second, SWS may be used to investigate the nature of the crust. Until now, most splitting measurements were performed using either teleseismic sources and interpreted in terms of mantle flow, or using local, midcrustal seismicity and interpreted in term of uppercrustal, microcrack-induced anisotropy related to upper-crustal stress states (e.g. Kaneshima et al., 1988; Peacock et al., 1988; Gledhill, 1991). Some recent seismic studies have nevertheless shown that it was possible to obtain an independent measurement of lower-crustal shear-wave splitting either by using $P$ to $\mathrm{S}$ conversion at the Moho transition (McNamara and Owens, 1993) or by using wide-angle seismic reflection experiments to detect this phenomenon (Clement et al., 1994). In these two studies, a delay time in the range $0.1-0.2 \mathrm{~s}$ has been measured and attributed to lower-crustal anisotropy. Laboratory seismic measurements performed by Christensen (1966) have already shown that crustal rocks can be strongly anisotropic for shear waves. More recent petrophysical investigations indicate that there is generally a close relationship between the intrinsic anisotropy (generated by preferred crystal orienta- tions), the birefringence, and the rock structure (foliation and lineation). This relationship may yield information on the crustal structure from shear-wave splitting studies (Kem and Wenk, 1990; Kem et al., 1991; Barruol and Mainprice, 1993a). Thus, both petrophysical and seismological developments are pointing the way towards use of SWS as a tool to investigate crustal nature and structure. It is therefore important to acquire new petrophysical data and particularly birefringence data on lower-crustal rocks.

In this paper, after a brief description of the geologic setting of the study area, we characterize the seismic properties of selected lower-crustal-upper-mantle samples. We used two different approaches: (1) direct laboratory measurements of seismic velocities on typical rocks from the Ivrea lower-crustal section; (2) calculations of the complete three-dimensional seismic properties of three samples based on the modal composition, the crystallographic preferred orientation of major minerals and the single crystal elastic constants. Both methods (direct laboratory measurements and calculations) were applied on several samples. We compare results and analyse discrepancies in Section 5. In Section 6, we attempt to characterize seismic properties at a more regional scale. Using the experimental data sets, we calculate average anisotropic seismic properties of hypothetical rocks that may be representative of the Ivrea lower crust. We finally discuss shearwave splitting in the lower crust in light of these new results.

\section{Geological description}

The Ivrea-Verbano Zone and the Serie dei Laghi are classically described as a crustal section through the lower crust of the Apulian plate which was uplifted and tilted during the alpine orogeny (e.g. Berckemer, 1968; Zingg et al., 1990). Generally, structures trend NE-SW (Fig. 1) and layering is steeply dipping. The Ivrea-Verbano Zone and the Serie dei Laghi are separated by vertical faults: the Pogallo line, which is interpreted as pre-tilting lowangle fault (Hodges and Fountain, 1984; Handy, 1987), and the Cossato-Mergozzo-Brissago line (Boriani et al., 1990), whose nature remains unclear. Several high-temperature shear zones have been rec- 


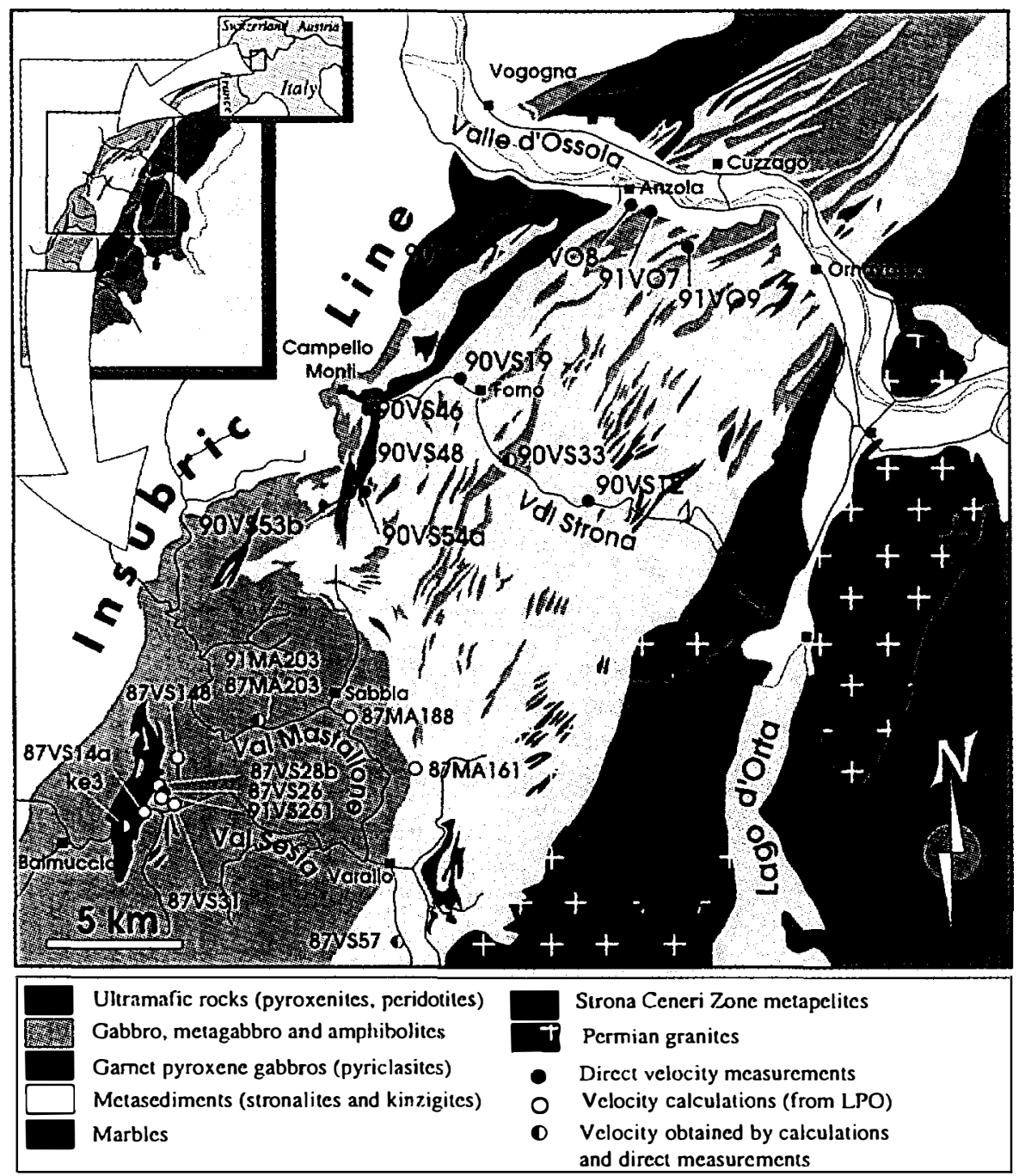

Fig. 1. Schematic map of the Ivrea Zone showing the various lithologic units (after Zingg, 1980; Brodie and Rutter, 1987). Sample locations and sample numbers are indicated. O. Samples used for the laboratory seismic measurements; $O$, samples used for the velocity calculations; 1 , samples for which both methods were applied.

ognized in the exposed lowermost parts of the crust and interpreted as ductile normal faults that accommodated post-Hercynian crustal extension (Brodie and Rutter, 1987; Rutter et al., 1993). The regional metamorphism increases to the west from greenschist to amphibolite facies in the Serie dei Laghi and from amphibolite to granulite facies in the Ivrea Zone (e.g. Sills and Tarney, 1984). Our study fo- cuses on the Ivrea-Verbano Zone, the lowermost level of this crustal section.

In the northern part of the study area, in the $\mathrm{Val}$ Strona and Valle d'Ossola (Fig. 1), the outcropping section comprises mainly a metasedimentary sequence composed of metapelites (kinzigites and stronalites) and marbles, and metabasic rocks such as amphibolites and pyriclasites (garnet-bearing 

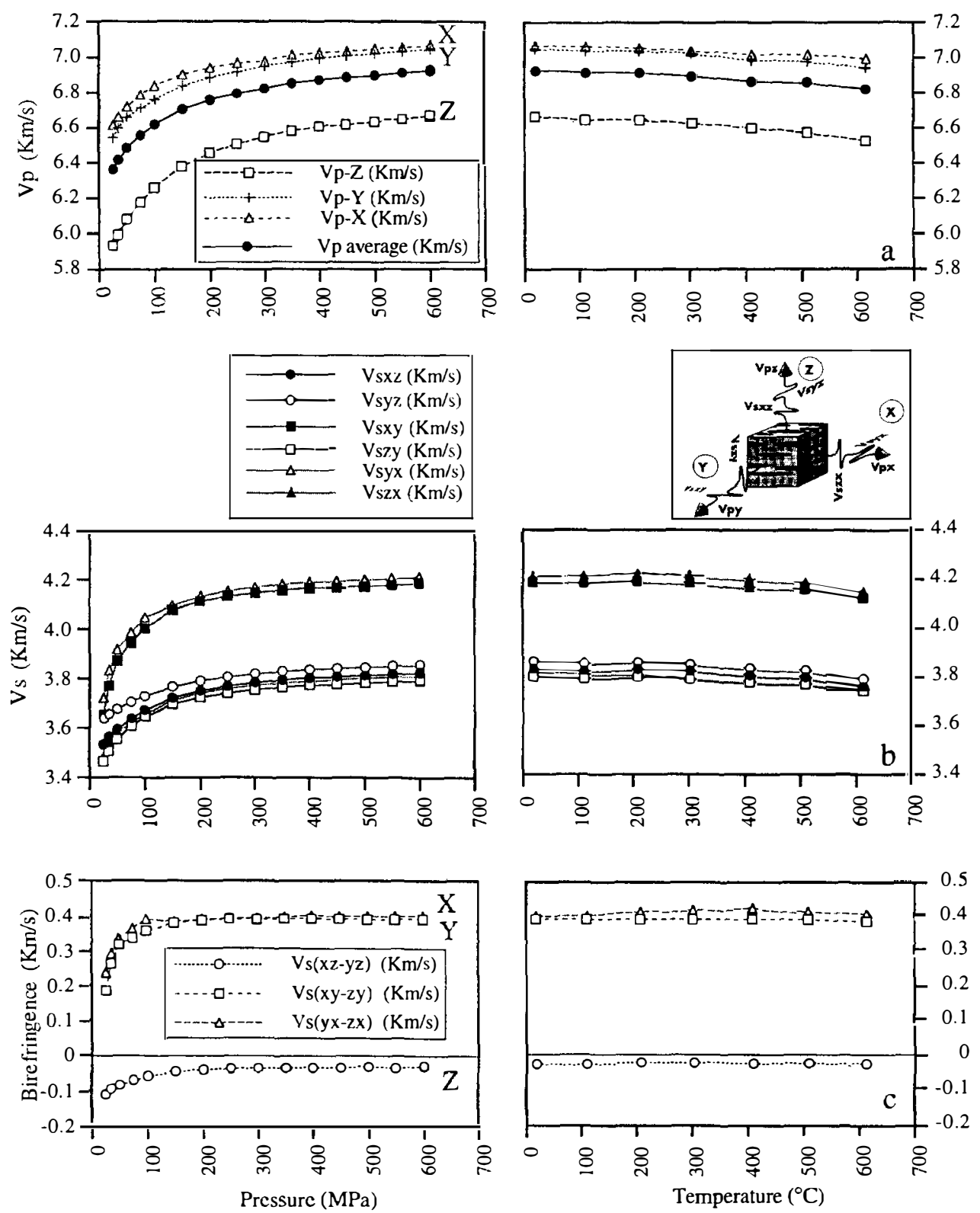

Fig. 2. Effect of pressure (at room temperature) and of temperature (at $600 \mathrm{MPa}$ ) on $\mathrm{P}$ - and S-wave velocities, for the amphibolite $90 \mathrm{VS} 33$. This rock is composed of homblende $(60 \%)$ and plagioclase $(40 \%)$. The three P-wave velocities measured along the three structural directions ( $x$, lineation; $y$ and $z$, pole of the foliation) and the corresponding average velocity are plotted in (a). The six shear-wave velocities are presented in (b). The shear-wave notation carries information about orientation and is similar to stress and strain notation (e.g. Nye, 1972): the first index indicates the direction of particle motion and the second the direction of wave propagation (see the insert). $V_{S_{x}:}$, for instance, is a shear wave propagating along the $z$ structural axis and polarized parallel to the $x$ axis. The birefringence along each direction is plotted in (c). The measured $\mathbf{P}$ - and $\mathrm{S}$-wave velocities display hexagonal symmetry: $\mathrm{P}$ waves propagate with nearly identical velocities along the $x$ and $y$ structural directions, whereas they propagate at a significantly lower velocity along the $z$ axis. The birefringence is also high and constant for propagation directions parallel to the foliation, whereas it is very low for waves propagating at high angle to the foliation. This property is generally due to a high amphibole or phyllosilicate content. The velocity anisotropy and the birefringence are not significantly affected by pressure and temperature. 
metagabbros). The petrography and metamorphism of these units have been extensively studied (e.g. Schmid, 1967; Zingg, 1980; Pin and Sills, 1986; Zingg et al., 1990). The whole section displays layering at a $10 \mathrm{~m}$ to $100 \mathrm{~m}$ scale. Several ultramafic bodies outcropping in the western part of the zone are thought to represent upper-mantle slices now incorporated within this lower-crustal section.

In the southern part of the area, in the Val Mastallone and the Val Sesia, a large vertically layered mafic body, $10 \mathrm{~km}$ thick, is exposed. This body is clearly intrusive into the metasedimentary sequence and displays clear magmatic microtextures (e.g. Quick et al., 1992). It is mainly composed of gabbroic material differentiated to diorites towards the top of the intrusion. The basal zone, defined as the Lower Layered Group by Rivalenti et al. (1981), is located between the Balmuccia peridotite massif and the mafic intrusion. It is about $1 \mathrm{~km}$ thick and made up by a layering (up to $50 \mathrm{~m}$ ) of mafic to ultramafic materials such as garnet-bearing metagabbros, pyroxenites, dunites, and also some lenses of metapelitic felsic rocks such as stronalites. These rocks display microstructural evidence to varying degree of plastic deformation under high metamorphic grade conditions. Numerous rock samples were collected from surface outcrops throughout the area in order to select samples with typical petrography, modal composition and microstructures for the laboratory measurements.

\section{Experimental measurements of seismic veloci- ties}

\subsection{Experimental devices}

Laboratory seismic velocity measurements were made in a 'cubic' pressure apparatus using the pulse transmission technique. Cubic samples ( $43 \mathrm{~mm}$ edge) were cut parallel to the main structural directions $x$, $y$ and $z$ (see insert Fig. 2). The P- and S-wave velocities were measured simultaneously along these three directions, first at increasing confining pressure (up to $600 \mathrm{MPa}$ ) at room temperature, and then at increasing temperature (up to 600 or $700^{\circ} \mathrm{C}$ ) at $600 \mathrm{MPa}$ confining pressure. Splitting of shear waves is obtained for each direction of propagation by two sets of oriented transducers with perpendicular polarization planes, and with the fast and the slow shear waves polarized parallel and normal to the main structural planes ( $x y, y z$ and $x z$ ). Each set of results is composed of nine velocities: three P-wave velocities and six S-wave velocities.

Table I

Modal composition of the studied samples

\begin{tabular}{|c|c|c|}
\hline Sample & Lithology & Modal composition \\
\hline $90 \mathrm{VS} 12$ & Amphibolite & $4.0 \mathrm{qz}, 35.0$ plagio, 59.0 hom, $1.0 \mathrm{ox}$ \\
\hline $90 V S 19$ & Stronalite & $55.0 \mathrm{qz}, 10.3 \mathrm{Kspar}, 8$ sill, 25.2 gar, $1.5 \mathrm{ox}$ \\
\hline 90VS 33 & Felsic amphibolite & 35.8 plagio, 54.2 hom, 8 pyrox, 2.0 ox \\
\hline 90 VS46 & Stronalite & 35 qz, 55 felds, 10 pyrox \\
\hline 90 VS 48 & Granulitic gabbro & 58 plagio, 23 pyrox, 19 hom \\
\hline 90 VS53b & Plagio pyroxenite & 25.4 plagio, 68.5 pyrox, 4.5 spi, 1.6 ox \\
\hline 90 VS54a & Quartzitic stronalite & $48.4 \mathrm{qz}, 37.0 \mathrm{Kspar}, 13.8$ pyrox, 0.8 ox \\
\hline $90 \mathrm{VS} 77 \mathrm{~b}$ & Pyriclasite & 47.0 plagio, 52 pyrox, 1 ox \\
\hline 91 VO7 & Metagabbro & 54 hom, 34 plagio, 11 pyrox, 1 ox \\
\hline $91 \mathrm{VO} 8$ & Stronalite & 42 qz, 28 plagio, $7 \mathrm{Kspar}, 14$ biot, 7 gar, 2 sill \\
\hline 87VS57 & Kinzigite & 45 biot, $22 \mathrm{Kspar}, 20$ qz, 8 sill, 5 gar \\
\hline 91MA203 & Magmatic gabbro & 76 plagio, 19 pyrox + hom, 5 ox \\
\hline 91 VS261 & Gamet gabbro & 30 plagio, 55 pyrox, 8 gar, 7 spi \\
\hline 91 VO9 & Stronalite & 35 q $<, 23 \mathrm{Kspar}, 17$ plagio, 8 biot, 7 sill, 10 gar \\
\hline ke3 & Lherzolite & 75 ol, 16 opx, 6 сpx, 3 spi \\
\hline per. 475 & Peridotite & 80 ol, 12 opx, 3 cpx, 3 serp, 2 ox \\
\hline
\end{tabular}

qz, quartz; plagio, plagioclase: Kspar, K-feldspar; hom, homblende; gar, gamet; sill, sillimanite; pyrox, pyroxene: cpx, clinopyroxene; opx, orthopyroxene; biot, biotite; spi, spinel; ol, olivine; serp, serpentine; cr, chromite; ox, oxide. 
Table 2

$\mathrm{P}$ - and S-wave velocities, anisotropy $(A)$, and S-wave birefringence along the three structural axes ( $x$, lineation; $z$, pole of foliation) measured at $600 \mathrm{MPa}$ for the 16 Iv rea-Verbano Zone samples

\begin{tabular}{|c|c|c|c|c|c|c|c|c|c|c|c|c|c|}
\hline Samples & $\begin{array}{l}V_{\mathrm{P}} / / x \\
\left(\mathrm{~km} \mathrm{~s}^{-1}\right)\end{array}$ & $\begin{array}{l}V_{\mathrm{p}} / / y_{1} \\
\left(\mathrm{~km} \mathrm{~s}^{-1}\right)\end{array}$ & $\begin{array}{l}V_{\mathrm{p}} / / z \\
\left(\mathrm{~km} \mathrm{~s}^{-1}\right)\end{array}$ & $\begin{array}{l}A V_{\mathrm{p}} \\
(\%)\end{array}$ & $\begin{array}{l}V_{S_{y, \lambda}} \\
\left(\mathrm{km} \mathrm{s}^{-1}\right)\end{array}$ & $\begin{array}{l}V_{\mathrm{S}: x} \\
\left(\mathrm{~km} \mathrm{~s}^{-1}\right)\end{array}$ & $\begin{array}{l}V_{\mathrm{s} x y} \\
\left(\mathrm{~km} \mathrm{~s}^{-1}\right)\end{array}$ & $\begin{array}{l}V_{\mathrm{S}: y} \\
\left(\mathrm{~km} \mathrm{~s}^{-1}\right)\end{array}$ & $\begin{array}{l}V_{S_{\lambda}=} \\
\left(\mathrm{km} \mathrm{s}^{-1}\right)\end{array}$ & $\begin{array}{l}V_{\mathrm{Sy}} \\
\left(\mathrm{km} \mathrm{s}^{-1}\right)\end{array}$ & $\begin{array}{l}V_{S(x:-y z)} \\
\left(\mathrm{km} \mathrm{s}^{-1}\right)\end{array}$ & $\begin{array}{l}V_{\mathrm{S}\left(x y-z^{y}\right)} \\
\left(\mathrm{kms} \mathrm{s}^{-i}\right)\end{array}$ & $\begin{array}{l}V_{\mathrm{S}(y x-i \lambda)} \\
\left(\mathrm{km} \mathrm{s}^{-i}\right)\end{array}$ \\
\hline $90 \mathrm{VS} 12$ & 7.48 & 7.04 & 6.53 & 12.74 & 4.07 & 3.95 & 4.09 & 3.84 & 3.79 & 3.92 & -0.128 & 0.250 & 0.120 \\
\hline $90 \mathrm{VS} 19$ & 7.25 & 6.92 & 6.55 & 9.61 & 4.02 & 3.99 & 4.04 & 3.87 & 3.86 & 3.86 & 0.000 & 0.172 & 0.025 \\
\hline 90VS46 & 6.13 & 6.03 & 6.13 & 1.75 & 3.83 & 3.88 & 3.87 & 3.83 & 3.84 & 3.79 & 0.057 & 0.023 & -0.047 \\
\hline $90 \mathrm{VS} 48$ & 6.86 & 6.78 & 6.89 & 1.74 & 3.81 & 3.82 & 3.82 & 3.81 & 3.79 & 3.78 & 0.016 & 0.009 & -0.003 \\
\hline $90 \mathrm{VS} 53 \mathrm{~b}$ & 7.33 & 7.16 & 7.19 & 2.35 & 4.09 & 4.09 & 4.04 & 3.97 & 3.97 & 4.10 & -0.123 & 0.0730 & 1.001 \\
\hline $90 \mathrm{VS} 54 \mathrm{a}$ & 7.36 & 7.10 & 6.63 & 9.96 & 4.29 & 4.26 & 4.17 & 4.23 & 4.15 & 4.13 & 0.015 & -0.060 & 0.028 \\
\hline $91 \mathrm{~V} 07$ & 7.47 & 7.05 & 7.02 & 6.24 & 4.10 & 4.11 & 4.08 & 3.96 & 3.92 & 4.10 & -0.184 & 0.123 & -0.014 \\
\hline 91 VO8 & 6.94 & 6.71 & 6.58 & 5.29 & 3.99 & 4.00 & 4.08 & 3.94 & 4.01 & 4.00 & 0.002 & 0.140 & -0.010 \\
\hline 87VS57 & 6.71 & 6.49 & 5.72 & 15.57 & 4.09 & 3.48 & 4.11 & 3.47 & 3.52 & 3.49 & 0.028 & 0.640 & 0.615 \\
\hline $91 \mathrm{MA} 203$ & 6.94 & 6.97 & 6.94 & 0.39 & 3.77 & 3.75 & 3.78 & 3.78 & 3.84 & 3.74 & 0.099 & 0.007 & 0.021 \\
\hline 91 VS261 & 7.10 & 7.01 & 6.85 & 3.48 & 3.91 & 3.88 & 3.92 & 3.85 & 3.81 & 3.86 & -0.057 & 0.069 & 0.024 \\
\hline 91VO9 & 6.41 & 6.22 & 5.89 & 8.42 & 3.75 & 3.59 & 3.84 & 3.71 & 3.54 & 3.72 & -0.182 & 0.134 & 0.161 \\
\hline ke3 & 8.49 & 8.38 & 7.90 & 7.15 & 4.87 & 4.70 & 4.83 & 4.62 & 4.73 & 4.65 & 0.077 & 0.215 & 0.176 \\
\hline Per. 475 & 8.67 & 8.32 & 8.12 & 6.34 & 4.73 & 4.74 & 4.84 & 4.65 & 4.76 & 4.59 & 0.170 & 0.190 & -0.001 \\
\hline \multicolumn{14}{|l|}{ Averages } \\
\hline Transition & 7.02 & 6.84 & 6.74 & 4.58 & 4.02 & 4.01 & 4.02 & 3.96 & 3.95 & 3.96 & -0.008 & 0.062 & 0.012 \\
\hline Crust & 7.02 & 6.84 & 6.63 & 5.55 & 4.01 & 3.90 & 4.01 & 3.87 & 3.85 & 3.88 & -0.036 & 0.146 & 0.101 \\
\hline Mean sample & 7.22 & 7.03 & 6.80 & 6.13 & 4.10 & 4.01 & 4.11 & 3.96 & 3.96 & 3.98 & -0.016 & 0.153 & 0.099 \\
\hline
\end{tabular}

Significance of shear-wave notation is described in insert, Fig. 2 , and its figure caption. In the lower part of the table are grouped the anisotropic seismic properties of hypothetical average samples representative of larger lithological units, which are deduced from the direct velocity measurements (see text for more explanations). 
Table 3

Bulk densities, average $\mathrm{P}$ - and $\mathrm{S}$-wave velocities and pressure and temperature derivatives of wave velocities

\begin{tabular}{|c|c|c|c|c|c|c|c|c|}
\hline \multirow[t]{2}{*}{ Samples } & \multirow[t]{2}{*}{$\begin{array}{l}\text { Density } \\
\left(\mathrm{g} \mathrm{cm}^{-3}\right)\end{array}$} & \multirow[t]{2}{*}{ Poisson } & \multicolumn{2}{|c|}{$\begin{array}{l}\text { Average } \\
\text { velocities } \\
\left(\mathrm{km} \mathrm{s}^{-1}\right)\end{array}$} & \multicolumn{2}{|c|}{$\begin{array}{l}\text { Pressure derivatives } \\
\text { (room temperature) } \\
\left(10^{-4} \mathrm{~km} \mathrm{~s}^{-1} \mathrm{MPa}^{-1}\right)\end{array}$} & \multicolumn{2}{|c|}{$\begin{array}{l}\text { Temperature derivatives } \\
(600 \mathrm{MPa}) \\
\left(-10^{-4} \mathrm{~km} \mathrm{~s}^{-1}{ }^{\circ} \mathrm{C}^{-1}\right)\end{array}$} \\
\hline & & & $V_{p}$ & $V_{\mathrm{S}}$ & $\mathrm{d} V_{\mathrm{p}} / \mathrm{d} P$ & $\mathrm{~d} V_{\mathrm{S}} / \mathrm{d} P$ & $\mathrm{~d} V_{\mathrm{p}} / \mathrm{d} T$ & $\mathrm{~d} V_{\mathrm{S}} / \mathrm{d} T$ \\
\hline $90 \mathrm{VS} 12$ & 3.183 & 0.27 & 7.02 & 3.94 & 3.62 & 1.73 & 2.71 & 1.66 \\
\hline $90 \mathrm{VS} 19$ & 3.096 & 0.26 & 6.91 & 3.94 & 4.52 & 2.04 & 5.51 & 2.45 \\
\hline $90 \mathrm{VS} 33$ & 3.111 & 0.26 & 6.92 & 3.95 & 3.21 & 1.26 & 1.92 & 1.26 \\
\hline $90 \mathrm{VS} 46$ & 2.753 & 0.17 & 6.09 & 3.83 & 4.52 & 1.80 & - & - \\
\hline $90 \mathrm{VS} 48$ & 2.897 & 0.28 & 6.85 & 3.80 & 4.68 & 1.49 & 2.34 & 1.48 \\
\hline $90 \mathrm{VS} 53 \mathrm{~b}$ & 3.280 & 0.27 & 7.23 & 4.04 & 3.48 & 1.02 & 3.99 & 1.99 \\
\hline $90 \mathrm{VS} 54 \mathrm{a}$ & 3.016 & 0.22 & 7.03 & 4.21 & 2.79 & 1.05 & 5.77 & 1.58 \\
\hline $90 \mathrm{VS} 77$ & 3.154 & 0.27 & 7.22 & 4.07 & 3.91 & 1.31 & 3.24 & 1.95 \\
\hline 91V07 & 3.087 & 0.27 & 7.18 & 4.05 & 5.28 & 2.00 & 1.74 & 1.17 \\
\hline $91 \mathrm{~V} 08$ & 3.011 & 0.23 & 6.74 & 4.00 & 4.22 & 1.91 & 5.54 & 2.50 \\
\hline 87VS57 & 2.864 & 0.24 & 6.31 & 3.69 & 5.81 & 2.35 & 5.20 & 2.54 \\
\hline $91 \mathrm{MA} 203$ & 2.942 & 0.29 & 6.95 & 3.80 & 3.80 & 0.83 & 2.33 & 1.24 \\
\hline 91 VS261 & 3.255 & 0.28 & 6.99 & 3.87 & 5.64 & 1.93 & 2.79 & 1.91 \\
\hline 91 VO9 & 2.847 & 0.22 & 6.17 & 3.69 & 7.34 & 2.57 & 3.48 & 1.57 \\
\hline ke3 & 3.360 & 0.25 & 8.25 & 4.75 & 2.16 & 0.36 & 6.43 & 4.82 \\
\hline Per. 475 & 3.316 & 0.27 & 8.37 & 4.72 & 2.36 & 0.95 & 4.94 & 3.93 \\
\hline \multicolumn{9}{|l|}{ Averages } \\
\hline Metapelites & 2.962 & 0.24 & 6.57 & 3.84 & 5.35 & 2.12 & 4.09 & 1.99 \\
\hline Transition & 3.030 & 0.24 & 6.87 & 3.98 & 4.02 & 1.52 & 4.40 & 1.99 \\
\hline Crust & 3.035 & 0.25 & 6.83 & 3.92 & 4.49 & 1.66 & 3.58 & 1.79 \\
\hline All samples & 3.070 & 0.25 & 7.01 & 4.02 & 4.21 & 1.54 & 3.86 & 2.14 \\
\hline
\end{tabular}

\subsection{Experimental results}

Fourteen lower-crustal samples and two mantle rocks were selected for the laboratory seismic measurements. Sample numbers, along with the modal compositions of the rocks, are listed in Table 1. The modes were determined by scanning electron microscopy (SEM) image analysis techniques using backscattered electrons (e.g. Lloyd, 1985).

The P- and S-wave velocities of the 16 specimens measured at $600 \mathrm{MPa}$ confining pressure (room temperature) are summarized in Table 2. For each sample we report the three $\mathrm{P}$-wave velocities, the $V_{\mathrm{P}}$ anisotropy, the six shear-wave velocities and the three corresponding birefringence values. At increasing pressure, $\mathrm{P}$ - and $\mathrm{S}$-wave velocities typically show a steep non-linear velocity increase up to $200-$ $300 \mathrm{MPa}$, which is interpreted as closure of microcracks (e.g. Kern, 1990). At higher pressures, a slight, linear increase of velocities is observed (see Fig. 2). Increase of temperature at high confining pressure $(600 \mathrm{MPa})$ results in a slight, linear decrease of the wave velocities. These linear velocity variations reflect the intrinsic rock properties which are controlled by the volume percentage of major minerals, their single crystal elastic properties, and their lattice preferred orientations (LPO). The pressure and temperature derivatives (see Table 3 ) were calculated from these linear trends and they allow one to extrapolate seismic velocities for any $P-T$ condition within the stability field of the constituent assemblage of rock-forming minerals. On the basis of the isotropic seismic velocities of these lower-crustal rocks, we also calculated their Poisson's ratios.

\section{Calculation of seismic velocities from lattice preferred orientations}

Seismic properties of three rock samples were calculated through the Christoffel equation (Crosson and Lin, 1971) combining single crystal densities, single crystal stiffness coefficients and LPO of the constitutive mineral phases, in their modal propor- 
tions. This enables us to determine the 21 elastic coefficients (the $6 \times 6$ symmetric matrix) characterizing the aggregate intrinsic elastic behaviour and the complete anisotropic seismic velocities $\left(V_{\mathrm{P}}, V_{\mathrm{S} 1}, V_{\mathrm{S} 2}\right.$, seismic birefringence, orientation of the shear-wave polarization planes...). Details of the calculation methods may be found in several studies (e.g. Baker and Carter, 1972; Peselnick et al., 1974; Siegesmund et al., 1989). We used a computer program developed by Mainprice (1990) for the calculations and the spatial representation of the seismic velocity variations. We made these velocity calculations on three samples: an amphibolite, a kinzigite and a lherzolite. Obviously, these three samples cannot be representative of the whole study area but they represent important lithologies and they add new and complementary data to the work of Barruol and Mainprice (1993b). The crystallographic measurements were performed with an optical microscope equipped with a universal stage using the methods already described by Barruol and Mainprice (1993b).

\subsection{Amphibolite 90VS33}

Automorphous and elongated grains of amphibole define a clear lineation. The grain size is typically in the range $0.2-1.0 \mathrm{~mm}$. The homblende crystallographic $c$-axes (Fig. 3(a)) form a strong maximum close to the lineation. $b$-Axes are grouped around the $y$ structural axis and the poles of the (100) planes are statistically oriented close to the pole of the foliation. Subautomorphous plagioclase grain size is around $0.5 \mathrm{~mm}$. In thin section, most of grains exhibit an albite twin (parallel to the (010) crystallographic plane) roughly parallel to the foliation. This kind of microstructure is typical of those observed in other Ivrea Zone mafic rocks. For this reason, we took as representative the plagioclase LPO measured in the pyroxene-rich gabbro 87VS14a sampled in the Val Sesia, in the same metamorphic grade (Barruol and
Mainprice, 1993b). This plagioclase fabric is characterized by $b$-axes concentrated close to the pole of the foliation and $c$-axes statistically oriented close to the lineation.

Single crystal elastic stiffness coefficients used in these calculations were reported by Aleksandrov and Ryzhova (1961) for homblende and by Aleksandrov et al. (1974) for plagioclase. P-Wave velocities in the hormblende single crystal exhibit a maximum close to the $c$-axis and a minimum close to the pole of the (100) plane. In the plagioclase single crystal, the maximum $V_{\mathrm{P}}$ is sub-parallel to the $b$-axis and the minimum is close to the $a$-axis. Despite the fact that plagioclase and homblende fabric have some destructive effects on the resulting anisotropy when summed together, hornblende (60\% of the rock) clearly controls the resulting $\mathrm{P}$-wave velocity distributions. The maximum $V_{\mathrm{P}}\left(7.2 \mathrm{~km} \mathrm{~s}^{-1}\right)$ corresponds to the amphibole lineation and the minimum $\left(6.5 \mathrm{~km} \mathrm{~s}^{-1}\right)$ to the pole of the foliation (Fig. 3(b)). The P-wave anisotropy is significant (10.9\%). The shear-wave properties of the amphibolite are also controlled by the amphibole fabric. The plagioclase single crystal birefringence displays a complex pattern (e.g. Siegesmund and Kruhl, 1991) and induces a weak birefringence for the plagioclase aggregate. On the other hand, the high birefringence (greater than $0.7 \mathrm{~km} \mathrm{~s}^{-1}$ ) of homblende single crystals in the (100) crystallographic plane and the low birefringence parallel to the $a$-axis are responsible for the pronounced shear-wave splitting (greater than $0.25 \mathrm{~km} \mathrm{~s}^{-1}$ ) parallel to the foliation ( $x y$-plane) with the fast shear wave polarized parallel to the foliation. Birefringence is very weak for propagation directions normal to the foliation.

\subsection{Kinzigite $87 V S 57 b$}

This metapelite (sedimentary rock metamorphosed in the amphibolite facies) was sampled in the

Fig. 3. (a), (c) and (e): lattice preferred orientations (LPOs) of three selected samples, presented on equal-area projection, in the structural reference frame $(x, y$ and $z$ ). Foliation is north-south (continuous line) and lineation north-south. Contour intervals: 1, 2, 3, 4, 6, 8, 12, $14 \%$. (b), (d) and (f): three-dimensional variations of the elastic properties of the corresponding rocks: P-wave velocities (left), variations of birefringence (middle) and orientation of the polarization planes of the fast split shear waves (right); each arc segment is part of a great circle corresponding to the orientation of the polarization plane. The modal composition of each rock is displayed in the pie diagram (right). (Note that contour intervals are not the same.) 


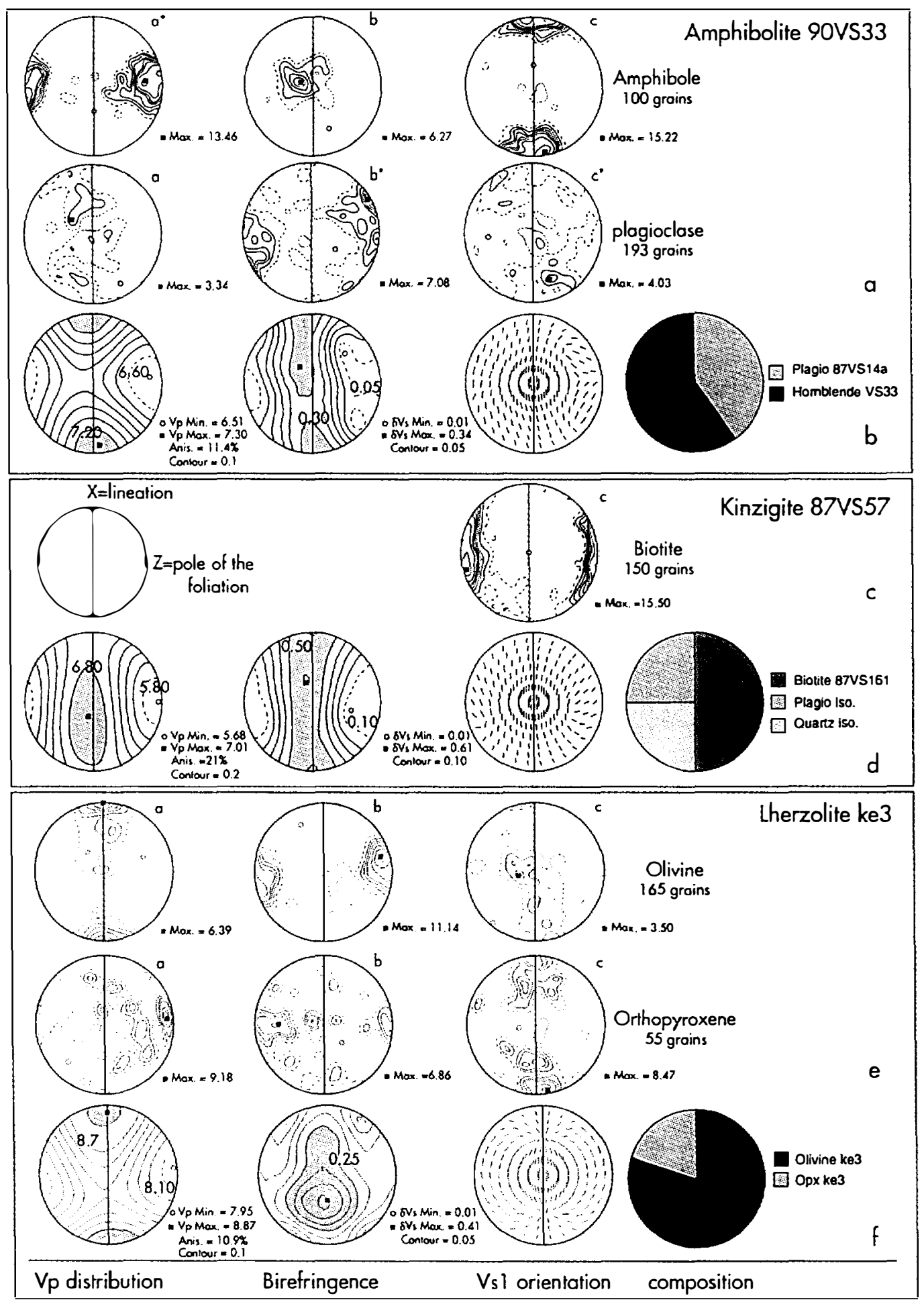


Val Sesia (Fig. 1). The rock exhibits a foliation strongly marked by flat biotite crystals. Biotite and sillimanite crystals are automorphous and their grain long axis is about $5 \mathrm{~mm}$. The biotite main cleavage (crystallographic plane $(001)$ ) is systematically oriented parallel to the foliation. Biotite LPO (Fig. 3(c)) was measured in a similar kinzigite (87MA 161; see location, Fig. 1) by Barruol and Mainprice (1993b). The quartz is xenomorphous and the grain size ranges from 0.2 to $1.0 \mathrm{~mm}$. Plagioclase grains are subautomorphous and their grain size is $0.5-1.0 \mathrm{~mm}$.

Thin section study revealed that quartz and plagioclase do not display evidence of preferred orientation. We therefore assumed a random orientation for these two minerals. The seismic properties of this metapelite were hence calculated using the biotite LPO. Muscovite single crystal stiffness coefficients (Vaughan and Guggenheim, 1986) were used for these calculations. Sillimanite has not been taken into account in these calculations. Burlini and Fountain (1993) quantified the role of the sillimanite in the seismic properties of the 'Serie dei Laghi' metapelites by direct velocity measurements and calculations. They showed that the crystallographic $c$ axes oriented close to the lineation generate a high $\mathrm{P}$-wave velocity in that direction. Sillimanite-rich metapelites (volume content greater than 15\%) therefore display orthorhombic properties for compressional waves. Sillimanite content in the kinzigite VS57 being around 5\%, we assumed this mineral may have only a second-order effect on the seismic properties. The whole-rock seismic properties (Fig. 3(d)) display a P-wave pattern with high velocities (greater than $6.8 \mathrm{~km} \mathrm{~s}^{-1}$ ) for waves propagating parallel to the foliation and significantly lower velocities (less than $5.8 \mathrm{~km} \mathrm{~s}^{-1}$ ) normal to the foliation, giving rise to a high $\mathrm{P}$-wave anisotropy $(21 \%)$. The shear-wave birefringence pattern displays a band of very high values (greater than $0.55 \mathrm{~km} \mathrm{~s}^{-1}$ ) parallel to the foliation. Fast split shear waves are furthermore systematically polarized parallel to the foliation plane. On the other hand, birefringence is very weak (less than $0.05 \mathrm{~km} \mathrm{~s}^{-1}$ ) for shear waves propagating normal to the foliation.

\subsection{Lherzolite ke3}

This lherzolite crops out within the Balmuccia peridotite massif. It is characterized by a typical coarse granular texture and displays evidence of plastic deformation. Olivine shows a classic LPO (Fig. 3(e)) with a strong maximum of [010]-axes close to the pole of the foliation whereas the [100] are parallel to the lineation. The orthopyroxene LPO is typical of upper-mantle rocks (e.g. Boudier et al., 1984): $a$-axes are grouped in a maximum close to the pole of the foliation. The $c$-axes form a band in the foliation plane with a maximum close to the lineation.

The stiffness coefficients of the olivine and pyroxene single crystals used for the calculations are those determined by Kumazawa and Anderson (1969) and by Weidner et al. (1978), respectively. The whole-rock seismic properties, and particularly the P-wave properties, are controlled by olivine, which represents the major volume of the rock (about $80 \%$ ). The rock slow $\mathrm{P}$-wave direction $\left(7.95 \mathrm{~km} \mathrm{~s}^{-1}\right)$ is parallel to the olivine [010]-axes (Fig. 3(f)). The [100]-axes (fast P-wave direction in olivine single crystals) concentrated close to the lineation induces a high $V_{\mathrm{P}}\left(8.87 \mathrm{~km} \mathrm{~s}^{-1}\right)$ in this direction. The shearwave properties of this rock are also controlled by the olivine fabric. The [010] olivine single crystal crystallographic direction is characterized by a weak birefringence. This explains the very weak birefringence (less than $0.05 \mathrm{~km} \mathrm{~s}^{-1}$ ) for shear waves propagating at high angle to the foliation. The olivine single crystal maximum birefringence is located between the [100] and [001] crystallographic axes. The band of [001]-axes parallel to the foliation with a maximum corresponding to the $y$ structural axis generates a highly birefringent zone (greater than $0.20 \mathrm{~km} \mathrm{~s}^{-1}$ ) within the foliation, with a maximum $\left(0.40 \mathrm{~km} \mathrm{~s}^{-1}\right)$ close to $y$. S-Wave seismic properties of kimberlite nodules (Mainprice and Silver, 1993) display the same pattems of high birefringence close to the $y$ direction. In the foliation plane, fast split shear waves are systematically polarized parallel to the foliation.

\section{Comparison between measured and calculated seismic properties}

Seismic properties were determined using laboratory measurements made on rock samples and/or calculations from petrofabric data. Both methods were applied to several samples. This enables us to 
compare the data and to analyse the discrepancies of the results obtained by both methods on four samples: the three samples studied in the present work (the metapelite VS57, the lherzolite ke3 and the amphibolite VS33) and one sample (the magmatic gabbro MA203) for which calculations were performed by Barruol and Mainprice (1993b). In this section, we compare measurements obtained at $600 \mathrm{MPa}$ confining pressure (to minimize the influence of the microcracks) with those calculated from the LPO.

Fig. 4 displays the ratio (in per cent) between measured and calculated seismic properties considering the medium as anisotropic for the P-waves using the seismic velocities measured along each structural axis $(x, y$ or $z)$ and considering the corresponding $\mathrm{P}$ and $S$ velocities. Several features stand out: (1) most of the calculated values show discrepancies in the range of about $\pm 5 \%$ compared with the measured ones; (2) for a given sample, variations between the various structural axes show little scattering (in a range of about 5\%); the average value between the three directions may hence be considered as representative and suitable for the comparison; (3) there is no systematic trend. The measured velocities are sometimes higher but also sometimes lower than calculated ones. The only parameter displaying a systematic variation is density. The measured density (obtained from the size and the weight of the cubic specimen) is systematically higher than the calculated density (obtained from the rock modal composition and the single crystal densities). Calculationderived densities are smaller than those derived from the volume and the mass of the sample cubes because the calculations do not take into account highdensity accessory minerals, such as Fe-oxides.

\subsection{Rock composition}

The modal composition of the rock is one of the main factors that controls the final results. Compositions were determined by image analyses of digitized views of thin sections obtained from SEM backscattered electrons. This approach enables us to determine directly for each image the surface area of each mineral phase. Samples (about $10 \mathrm{~cm}^{2}$ ) were digitized in several images (10-20, depending on the rock grain size). Discrepancies between our measured and calculated results arise in two ways: (1) The composition measured from thin sections may differ from the cube specimen; (2) in the calculations we do not take into account mineral phases that represent less than $5 \%$ of the rocks. For example, oxides may strongly influence the seismic properties.

Seismic properties

Measured/calculated-Voigt (\%)

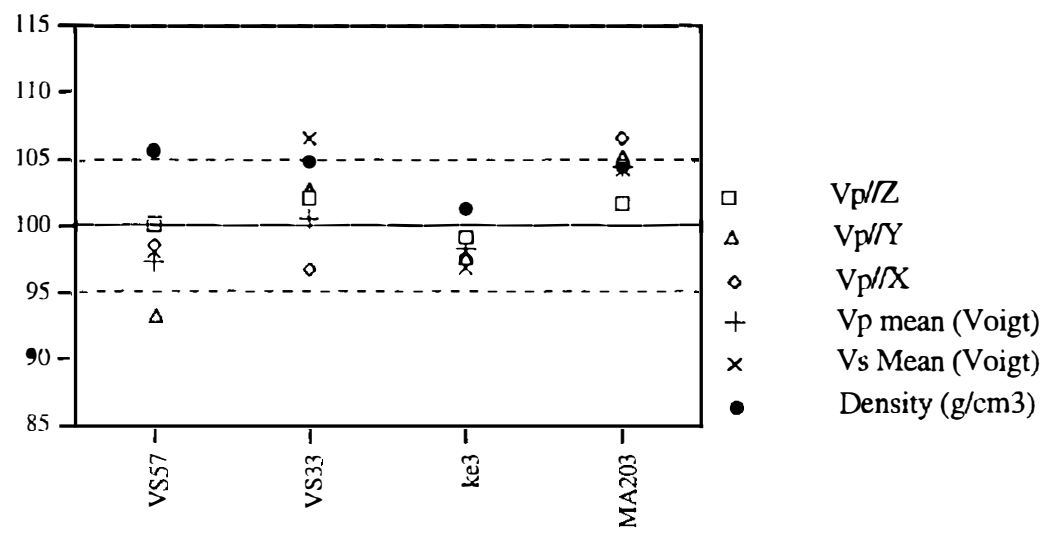

Fig. 4. Comparison between measured and calculated seismic properties of four samples on which both methods were applied. Ratio (in per cent) between the measured and calculated values of the P-wave velocities (Voigt average) along the three structural axes ( $x$, lineation; $y$ and $z$, pole of the foliation) and also between the measured and calculated density, and $V_{\mathrm{S}}$. A ratio of $100 \%$ means that we obtained the same results from laboratory measurements and calculations. This diagram clearly shows that the differences between measured and calculated properties are in the range $\pm 5 \%$. 


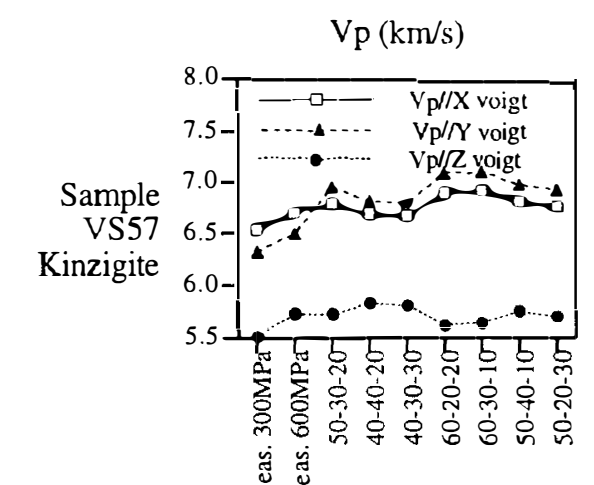

Birefringence $(\mathrm{km} / \mathrm{s})$

Densities
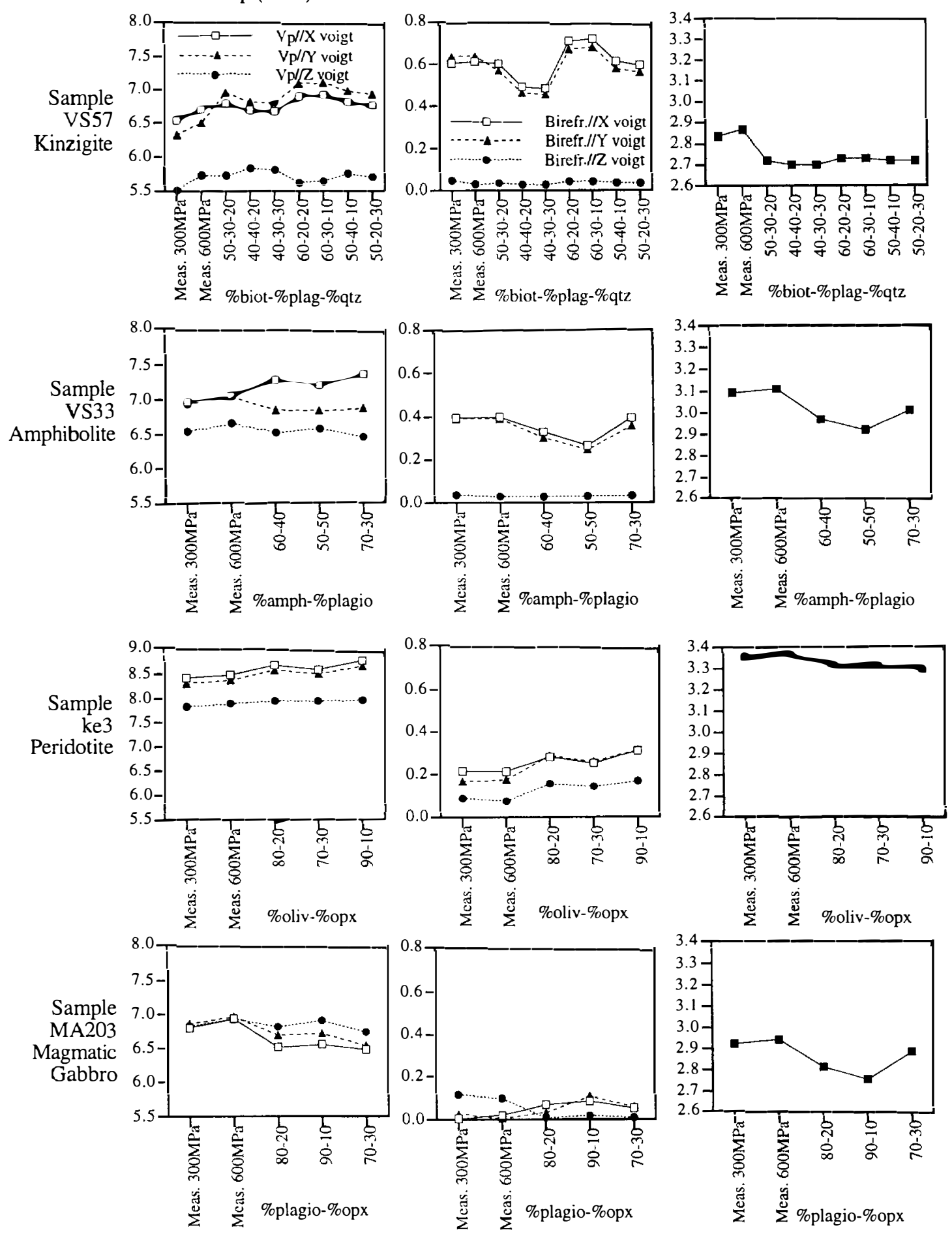
To quantify the influence of the composition on the resulting seismic properties, we calculated for the four samples the three most important seismic parameters for various compositions: the P-wave velocity, the birefringence and the rock density, and we compare these values with the measured ones. Results for each sample are grouped together in Fig. 5. Each diagram displays the values measured at 300 and $600 \mathrm{MPa}$ confining pressure (this allows one to have an idea of the pressure derivatives), the calculated values for measured composition, and the calculated values with slightly different compositions: for each rock we calculated the seismic properties considering variations of $\pm 10 \%$ in the proportions of each mineral phase (see explanation in the figure caption).

The diagrams in Fig. 5 display the following general features:

1. there is no systematic variation. Calculated $V_{\mathrm{P}}$ is generally higher than measured for the kinzigite and the lherzolite sample but the gabbro MA203 displays lower calculated $\mathrm{P}$-wave velocities.

2. The general behaviour of the anisotropy compares fairly well: for both P-wave velocities and birefringences, the hierarchical organization between the three structural axes is well preserved (for example $V_{\mathrm{P}_{y}}>V_{\mathrm{P}_{y}}>V_{\mathrm{P}_{z}}$ ), except when the absolute differences are small. For instance, the kinzigite VS57 has the following birefringence pattern: a very small value along the $z$ structural axis and high values along the $x$ and $y$ axes. The highest measured birefringence is along the $y$ axis whereas the highest calculated birefringence is along the $x$ axis, but in both cases the intermediate birefringence is very close to the maximum. This qualitatively important discrepancy (the maximum calculated is oriented along the $x$ and not the $y$ structural direction as measured) is not quantitatively fundamental because the absolute variations are small. The measured and calculated birefringence patterns of the gabbro MA203 are differently organized but the absolute values are very weak (less than $0.10 \mathrm{~km} \mathrm{~s}^{-1}$ ) and this difference may not be considered as inconsistent.

3. Fig. 5 shows that a relatively small number of mineral phases controls the main seismic properties. Biotite and amphibole control the anisotropy of the kinzigite and the amphibolite, respectively. On the other hand, plagioclase does not appear to play an important role: the variations of the plagioclase content $( \pm 10 \%)$ in the gabbro MA203 generate minor variations in the $\mathrm{P}$-wave velocities and weak and complex variations in the birefringence.

\subsection{Densities}

The difference between the measured and the calculated densities cannot directly explain the differences between the two methods. Comparisons of densities in Fig. 5 show that calculated values are generally lower than measured. On the other hand, calculated P-wave velocities are generally higher than measured. For a given rock, characterized by its elastic stiffness matrix, the effect of a higher density in the velocity calculations would be to increase the calculated velocities and therefore to separate the calculated velocities from the measured slightly more. Only the gabbro MA203 displays compatible $V_{\mathrm{P}}$ and density trends: both calculated velocities and densities are lower than measured velocities and densities.

\subsection{Microfractures and porosity}

The effect of microfracturing on seismic anisotropy may be inferred from Fig. 6, in which the measured $V_{\mathrm{P}}$ anisotropy is plotted against the confining pressure. These curves display the variation of anisotropy, i.e. the variations of the differences between the minimum and maximum $V_{\mathrm{p}}$. In a medium

Fig. 5. Influence of the rock composition in the comparison between measured and calculated seismic properties for the four samples on which both techniques were applied. $V_{\mathrm{P}}$ is shown on the left, birefringence in the middle and density on the right. The diagrams show the measured properties for the three structural directions (at 300 and $600 \mathrm{MPa}$ ) and the calculated ones for different modal compositions. From the initial composition of the rock, seismic properties were calculated for variations of $\pm 10 \%$ of the amount of each mineral phase in the rock. For the kinzigite VS57, for example, 50-30-20 (horizontal axis) means that the calculation was performed using 50\% biotite, 30\% plagioclase and $20 \%$ quartz. 


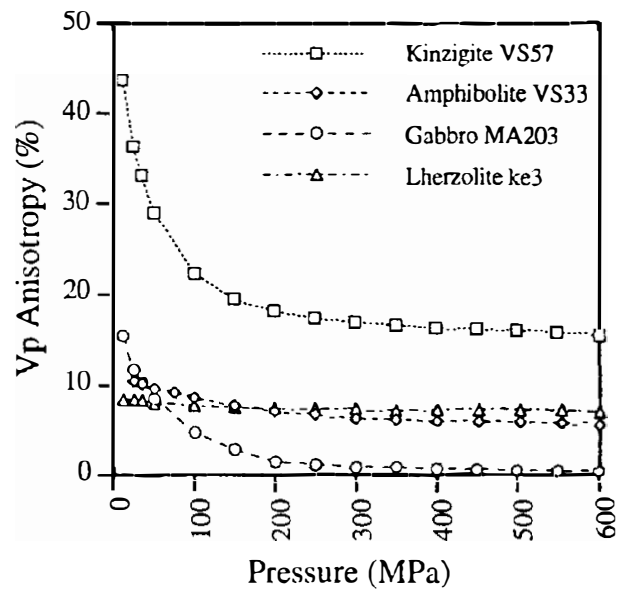

Fig. 6. Effect of confining pressure on P-wave anisotropy for the four samples on which seismic properties were calculated and experimentally determined. The large variations of anisotropy for the kinzigite and the gabbro indicate that these rocks are affected by non-randomly oriented microfractures. The velocity vs. pressure relations of the amphibolite and the lherzolite indicate that either there are few initial microcracks or that the microcracks are randomly oriented.

with a randomly distributed crack fabric, the overall anisotropy should remain constant with increase of pressure (isotropic sample compaction). The lherzolite ke3 and the amphibolite VS33 do not display strong variations of anisotropy with increasing pressure. This means that either there are no cracks in the specimen or these cracks have no preferred orientations. Above $300 \mathrm{MPa}$, anisotropy varies slightly and the slope is quasi-linear. This is controlled by the preferred orientation of minerals (e.g. Kern and Wenk, 1990; Siegesmund and Vollbrecht, 1991). Below 200-300 MPa, the anisotropy may be strongly affected by pressure variations. This is related to the preferred orientation of microcracks which are progressively closed as pressure increased. The strong variation of seismic anisotropy for the kinzigite VS57 and the gabbro MA203 clearly indicates the presence of preferred orientation of the microfractures in the specimen.

\subsection{Measured lattice preferred orientations (LPO)}

Two major problems related to the petrofabric data may arise when calculating seismic properties:

1. owing to the difficulty of acquiring the crystallo- graphic orientations of some minerals, caused by their low crystallographic symmetry (the plagioclase triclinic, for instance), or because of the small grain sizes, the orientation fabrics of these mineral species may have to be considered as random. We made this assumption for the quartz and the plagioclase in the kinzigite sample, and in that particular case the comparisons with the direct velocity measurements show fairly good agreements. This is a result of the overwhelming control of the biotite on the seismic properties.

2. The measured LPO may not be representative for the rock. This can arise if the number of measured grains is too small. Moreover, a representative measurement of the LPO for low-symmetry minerals (monoclinic and triclinic minerals; plagioclase, for instance) is difficult to obtain, because many crystals are not appropriately oriented to be measurable. This may result in a grain selection in the fabric. To avoid or at least to minimize this problem, plagioclase crystallographic orientations were measured on two perpendicular sections (Barruol and Mainprice, 1993b).

\subsection{The calculation assumptions}

The calculation of the elastic properties of polymineralic aggregates is based on the Voigt, Reuss or Hill approximations. The Voigt average assumes a uniform strain inside the sample, the Reuss average a uniform stress, and the Hill assumption corresponds to the arithmetic mean of the Voigt and Reuss bounds. Mainprice and Humbert (1994) showed that the differences between the two approximations increase with increase in the aggregate anisotropy. In particular, shear waves are more affected than Pwaves. We have calculated the velocities of these rocks with the different average assumptions and compared the results with the data. The results show no systematic trend. The Voigt assumption is more consistent with the measured values for samples VS57 and VS33, but the Reuss assumption is slightly better for the lherzolite ke3 and the gabbro MA203. Except for the gabbro MA203, the calculated P-wave velocities generally give a better fit (in the range $\pm 5 \%$ ) to the measurements than do the $S$-waves (in the range $\pm 10 \%$ ). These observations clearly indi- 
cate that some differences between measured and calculated velocities may be explained by these assumptions.

In conclusion, the calculated and measured seismic properties are comparable, at least to a first approximation. Despite some simplifications used for two samples (mineral phase considered as isotropic and LPO obtained on a different sample), qualitative (orientation of fast and slow velocities, for example) and quantitative (magnitude of the velocities, birefringence) results are in reasonable agreement, within the $95 \%$ confidence interval. Part of the observed discrepancies may be attributable to inaccuracies in the determination of the modal composition of the rock, to the calculation assumptions, to inaccuracies in the single crystal elastic constants (particularly for the plagioclase) and to non-modelled variations of the lattice preferred orientations. But we cannot rule out other factors, such as the degree of alteration and the effect of grain shapes and phase contiguity that are not taken into account in the calculations. Also, experimental problems such as the fixed shear-wave transducer orientations or the presence of large velocity gradients within some samples may affect our results.

\section{Bulk anisotropic properties of the lower crust}

The extrapolation of laboratory measurements to results from field seismic experiments is problematic for seismologists and petrophysicists. Laboratory-derived seismic properties are obtained using a wavelength of a few millimetres and the results are inter- preted at a scale of a few centimetres. In seismic field experiments, by contrast, seismic waves sample the anisotropy at scales of hundreds of metres to tens of kilometres. Geophysicists therefore require an overview of the crustal seismic properties at a larger scale. To characterize better the regional seismic anisotropy of the lower crust in the Ivrea Zone, we calculated the seismic properties of hypothetical samples which could be more representative of the 'average' lower crust than each sample considered individually. The seismic properties of these hypothetical samples are obtained by averaging individual seismic properties of rocks that can be found in the same area, based on the velocities measured at $600 \mathrm{MPa}$ confining pressure and room temperature (see Table 2) or on the calculated velocities. The regional structure (foliation and lineation) of the study area is found to be roughly constant so that most of the rock samples were similarly oriented originally. Averaging the physical properties is therefore based on the assumption that their structural axes (lineation, pole of the foliation) have similar orientations in the geographic reference frame (Burlini, 1994). This enables us to average simply the seismic velocities measured along the various structural axes.

From the laboratory data, we calculated the average properties of the crust, using the 14 crustal samples and the average properties of the IvreaVerbano Zone through the 16 crustal and mantle rocks. A striking feature is that the average velocities of the 14 crustal samples do not yield an isotropic result. Furthermore, there are clear relationships between the anisotropy and the structural reference
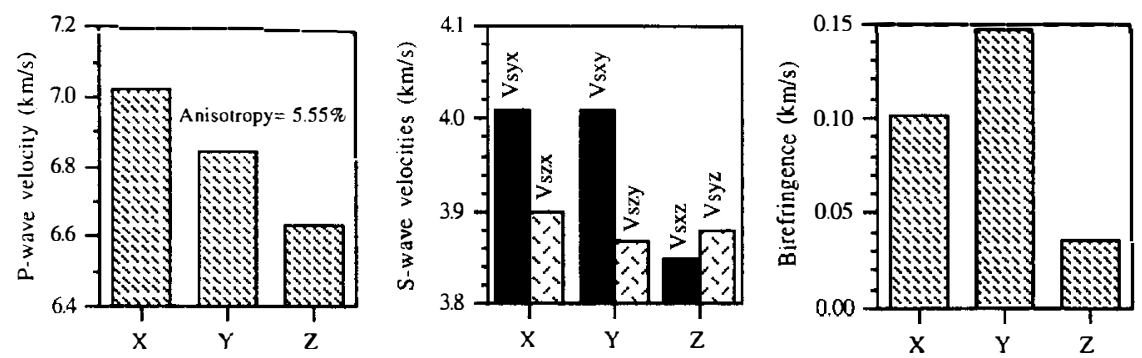

Fig. 7. Anisotropic seismic properties of the hypothetical sample representing the mean properties of the lower crust in the Ivrea Zone. The data correspond to the average of the laboratory-derived seismic properties of the 14 crustal samples. Despite the number of samples taken into account and their different natures, the P-wave velocities (left), the S-wave velocities (middle) and the birefringence (right) for the three structural axes ( $x, y$ and $z$ ) clearly indicate that the average sample is not isotropic at all. 
frame: the average crustal P-wave velocities (Fig. 7, left) are fast $\left(7.0 \mathrm{~km} \mathrm{~s}^{-1}\right)$ parallel to the lineation $(x$ structural direction) and slow $\left(6.6 \mathrm{~km} \mathrm{~s}^{-1}\right)$ normal to the foliation. The calculated average velocity anisotropy for $\mathrm{P}$ waves is $5.55 \%$. The average crustal S-wave velocities are also strongly related to the structural reference frame. The mean anisotropic shear-wave velocities display a variation pattern already described in several samples (e.g. amphibolite VS33). The mean velocities calculated from the 14 crustal samples (Fig. 7, middle) display the following properties: $\mathrm{S}$-waves propagate at high velocities $\left(4.01 \mathrm{~km} \mathrm{~s}^{-1}\right)$ when they are polarized parallel to the foliation plane $\left(V_{s y x}\right.$ and $\left.V_{S x y}\right)$. S waves have much lower velocities (average $3.87 \mathrm{~km} \mathrm{~s}^{-1}$ ) when they are polarized normal to the foliation. The birefringence (Fig. 7, right) is therefore high for waves propagating parallel to the foliation $\left(0.101\right.$ and $0.146 \mathrm{~km} \mathrm{~s}^{-1}$ parallel to $x$ and $y$, respectively), and smaller $\left(0.036 \mathrm{~km} \mathrm{~s}^{-1}\right)$ in directions at a high angle to the foliation plane.

Considering the fact that seismic waves in real seismic experiments may not sample the whole Ivrea Zone, we calculated the seismic properties of two other hypothetical samples more representative of the actual geology: one sample representing the metapelitic part of the study area and the other representing the lower-crust-upper-mantle transition zone. We based our calculations on lithologies that can be found in Val Strona and Valle d'Ossola (Fig. 1). The hypothetical 'metapelite' sample could be representative of the eastern part of the Val Strona or Valle d'Ossola, which is dominated by metapelitic lithologies. The seismic properties of this sample are calculated on a basis of $75 \%$ of metasediments (using the seismic properties of the kinzigite VS57 and stronalites VO8 and VO9) and 25\% of mafic rocks (metagabbro VO7 and amphibolites VS33 and VS 12). These ratios roughly represent the outcropping proportions of the different lithologies.

'Metapelite' seismic properties

$$
\begin{gathered}
=[\mathrm{VO} 8+\mathrm{VO} 9+\mathrm{VS} 57+(\mathrm{VO} 7 / 3) \\
+(\mathrm{VS} 33 / 3)+(\mathrm{VS} 12 / 3)] / 4
\end{gathered}
$$

The second hypothetical sample, called 'transition', could be representative of the crust-mantle transition of the northern Ivrea Zone, i.e. of the westermost $5 \mathrm{~km}$ of the study area. The lower part of this crust is not dominated by a particular lithology and therefore we calculated the 'transition' sample properties from the arithmetic mean of the seven westernmost samples:

$$
\begin{aligned}
& \text { 'Transition' seismic properties } \\
& \begin{aligned}
= & {[\mathrm{VO} 8+\mathrm{VO} 77+\mathrm{VS} 46+\mathrm{VS} 19+\mathrm{VS} 48} \\
& +\mathrm{VS} 54 \mathrm{a}+\mathrm{VS} 53 \mathrm{~b}] / 7
\end{aligned}
\end{aligned}
$$

The 'metapelite' sample is characterized by much lower mean seismic velocities $\left(V_{\mathrm{p}}=6.57 \mathrm{~km} \mathrm{~s}^{-1}, V_{\mathrm{S}}\right.$ $\left.=3.84 \mathrm{~km} \mathrm{~s}^{-1}\right)$ than the 'transition' sample $\left(V_{\mathrm{P}}=\right.$ $\left.6.87 \mathrm{~km} \mathrm{~s}^{-1}, V_{\mathrm{S}}=3.98 \mathrm{~km} \mathrm{~s}^{-1}\right)$. The main difference between these two samples is their birefringence. The 'metapelite' sample displays a birefringence pattern typical for metasedimentary rocks: a weak birefringence $\left(0.067 \mathrm{~km} \mathrm{~s}^{-1}\right)$ for waves propagating normal to the foliation and a relatively high birefringence (greater than $0.23 \mathrm{~km} \mathrm{~s}^{-1}$ ) for waves propagating parallel to the foliation. On the other hand, the 'transition' sample is weakly birefringent (less than $0.06 \mathrm{~km} \mathrm{~s}^{-1}$ ) in the three structural directions. This is mainly due to mafic rocks (gabbros, pyroxenites), which are generally less anisotropic than biotite- or amphibole-bearing rocks.

The lithologies found in the northern part of the Ivrea Zone cannot be extrapolated to the southern part of the studied area (Val Sesia and Val Mastallone). For this reason, we have calculated the elastic properties of two supplementary hypothetical average samples that characterize the large-scale seismic properties of the Val Sesia section, from the petrofabric data obtained by Barruol and Mainprice (1993b).

The seismic properties of the 'transition Val Sesia' sample are the average of five typical samples that can be found in the $1 \mathrm{~km}$ thick layered mantle-crust transition at the contact with the Balmuccia peridotite body (the pyroxenite VS28b, the dunite VS148, the sheared pyroxenite VS14a, the sheared gabbro VS26 and the stronalite VS31). The seismic properties of this hypothetical sample are almost isotropic for both $\mathrm{P}$ waves (2.2\% anisotropy) and shear waves (maximum anisotropy $1.7 \%$ ). This is a consequence of the weak anisotropy of mafic rocks such as pyroxenites and gabbros. Among these five samples, only the dunite displays an important $V_{\mathrm{P}}$ anisotropy (9.7\%) and a strong birefringence $\left(0.30 \mathrm{~km} \mathrm{~s}^{-1}\right)$. 
The 'intrusion Val Sesia' sample is our attempt to characterize the seismic properties of the gabbro to diorite mafic intrusion. Its elastic constants were determined using $75 \%$ of the magmatic gabbro MA203 and 25\% of the diorite MA188. The corresponding calculated seismic properties define the same pattern as the gabbro MA203, but the overall anisotropy is lower than for this rock ( $V_{\mathrm{P}}$ anisotropy $3.5 \%$ and maximum birefringence $0.10 \mathrm{~km} \mathrm{~s}^{-1}$ ).

We used the nine seismic velocities (three $\mathrm{P}$ waves and six S waves; see Table 2) of each hypothetical sample to determine the stiffness coefficients characterizing their elastic properties (Table 4). These constants enable one to extrapolate the seismic velocities to the whole space. The number of direct measurements enables us to determine only the elastic coefficients assuming the medium has an axial symmetry. We used the transformation relationships reported by Christensen and Crosson (1968) and made the two required assumptions: (1) the medium has transversely isotropic elastic properties around the $z$ structural axis (this holds particularly for the $S$ waves; see, for instance, Fig. 7, but is sometimes less true for the $\mathrm{P}$ waves); (2) the P-wave velocity in a direction at $45^{\circ}$ between the $x$ and $z$ structural axes corresponds to the average value between $V_{\mathrm{Pr}}$ and $V_{\mathrm{Pz}}$. The calculation of the elastic stiffness coefficients is based on the P-wave velocity parallel to the $z$-axis, on the $\mathrm{P}$-wave velocities parallel to the foliation (defined as $\left.V_{\mathrm{P} x}=V_{\mathrm{P} y}=\left(V_{\mathrm{P} x}+V_{\mathrm{P} y}\right) / 2\right)$, on the values of the two fast shear waves (defined as $V_{S y x}$ $\left.=V_{\mathrm{S} x y}=\left(V_{\mathrm{S} x y}+V_{\mathrm{S} y x}\right) / 2\right)$, and on the other four $S$-wave velocities corresponding to the average of the four velocities $\left(V_{\mathrm{Sz}}=V_{\mathrm{S} z y}=V_{\mathrm{S} x z}=V_{\mathrm{S} y z}=\right.$

Table 4

Calculated stiffness coefficients of the elastic tensor $C_{1}$, characterizing the elastic properties of the three selected samples and the hypothetical average samples

\begin{tabular}{|c|c|c|c|c|c|c|c|c|c|}
\hline $\begin{array}{l}C_{i j} \\
(\mathrm{GPa})\end{array}$ & $\begin{array}{l}\text { Average } \\
\text { metapelites }\end{array}$ & $\begin{array}{l}\text { Average } \\
\text { transition }^{\text {a }}\end{array}$ & $\begin{array}{l}\text { Average } \\
\text { lvrea Zone } \\
\text { ( } 14 \text { crustal } \\
\text { samples) }\end{array}$ & $\begin{array}{l}\text { Average } \\
\text { Ivrea Zone } \\
(16 \text { samples) }\end{array}$ & $\begin{array}{l}\text { Amphibolite } \\
\text { VS.33 }\end{array}$ & $\begin{array}{l}\text { Kinzigite } \\
\text { VS57 }\end{array}$ & $\begin{array}{l}\text { Lherzolite } \\
\text { ke } 3^{\text {b }}\end{array}$ & $\begin{array}{l}\text { Transition } \\
\text { Val Sesia }^{c}\end{array}$ & $\begin{array}{l}\text { Intrusion } \\
\text { Val Sesia }\end{array}$ \\
\hline$C_{11}$ & 134.47 & 145.52 & 145.76 & 156.07 & 158.15 & 125.53 & 260.06 & 193.74 & 136.78 \\
\hline$C_{22}$ & 134.47 & 145.52 & 145.76 & 156.07 & 126.42 & 88.60 & 210.10 & 199.19 & 144.29 \\
\hline$C_{33}$ & 114.89 & 137.65 & 133.41 & 141.96 & 139.46 & 131.11 & 236.46 & 194.96 & 140.44 \\
\hline$C_{44}$ & 41.85 & 47.76 & 45.45 & 48.63 & 38.66 & 35.60 & 73.80 & 65.74 & 45.16 \\
\hline$C_{55}$ & 41.85 & 47.76 & 45.45 & 48.63 & 45.45 & 47.49 & 83.83 & 64.83 & 43.44 \\
\hline$c_{66}$ & 47.83 & 48.97 & 48.80 & 51.73 & 38.45 & 35.32 & 77.63 & 65.10 & 44.81 \\
\hline$C_{12}$ & 38.80 & 47.58 & 48.15 & 52.60 & 57.73 & 29.70 & 70.57 & 64.99 & 53.05 \\
\hline$C_{13}$ & 42.89 & 46.34 & 49.34 & 52.57 & 58.99 & 33.63 & 74.55 & 65.36 & 50.71 \\
\hline$C_{14}$ & 0.00 & 0.00 & 0.00 & 0.00 & -1.10 & 0.49 & 0.04 & -0.11 & 0.21 \\
\hline$C_{15}$ & 0.00 & 0.00 & 0.00 & 0.00 & -0.56 & -1.54 & -2.70 & 0.02 & 0.15 \\
\hline$C_{16}$ & 0.00 & 0.00 & 0.00 & 0.00 & 1.44 & -0.14 & 1.79 & 1.15 & -1.52 \\
\hline$C_{23}$ & 42.89 & 46.34 & 49.34 & 52.57 & 53.84 & 29.59 & 72.47 & 65.27 & 53.49 \\
\hline$C_{24}$ & 0.00 & 0.00 & 0.00 & 0.00 & 1.38 & 1.71 & -0.79 & 1.57 & 0.28 \\
\hline$C_{25}$ & 0.00 & 0.00 & 0.00 & 0.00 & -1.31 & 0.34 & -0.07 & 0.46 & 0.01 \\
\hline$C_{26}$ & 0.00 & 0.00 & 0.00 & 0.00 & -0.56 & 0.26 & 1.74 & 0.69 & -1.59 \\
\hline$C_{34}$ & 0.00 & 0.00 & 0.00 & 0.00 & 1.99 & 4.31 & -1.89 & 0.77 & 0.36 \\
\hline$C_{35}$ & 0.00 & 0.00 & 0.00 & 0.00 & -0.59 & -1.86 & -3.50 & 0.69 & 0.53 \\
\hline$c_{36}$ & 0.00 & 0.00 & 0.00 & 0.00 & 0.19 & -0.30 & 0.77 & 0.20 & -0.05 \\
\hline$C_{45}$ & 0.00 & 0.00 & 0.00 & 0.00 & 0.15 & -0.36 & 0.81 & 0.72 & 0.56 \\
\hline$c_{46}$ & 0.00 & 0.00 & 0.00 & 0.00 & -0.24 & -0.33 & -1.60 & 0.40 & 0.05 \\
\hline$C_{56}$ & 0.00 & 0.00 & 0.00 & 0.00 & 1.34 & 2.02 & -0.40 & 0.58 & 0.05 \\
\hline
\end{tabular}

${ }^{\mathrm{a}} C_{i}$, characterizing geologic units but calculated from direct velocity measurements. Null values are derived from the fact that the nine measured seismic velocities do not enable one to determine the complete elastic tensor.

${ }^{\mathrm{b}} C_{i}$, characterizing a single rock elastic properties, calculated from the lattice preferred orientations (LPO) of the constitutive mineral phases, the single crystal elastic constants and densities.

${ }^{c} C_{i}$, characterizing a geologic unit by averaging several single rocks' elastic matrixes. 
$\left.\left(V_{\mathrm{S} z x}+V_{\mathrm{S}_{z y}}+V_{\mathrm{S} x z}+V_{\mathrm{S}_{y z}}\right) / 4\right)$. The resulting stiffness tensors $\left(C_{i j}\right)$ describing the average elastic properties of these hypothetical samples are listed in Table 4.

\section{Shear-wave splitting in the lower crust}

Our calculations clearly show that the mafic rocks such as gabbros and pyroxenites are not efficient generators of significant shear-wave splitting. On the other hand, as already shown by several workers (Siegesmund et al., 1989; Burlini and Fountain, 1993; $\mathrm{Ji}$ and Salisbury, 1993; Barruol and Mainprice, 1993a), amphibole- and phyllosilicate-bearing rocks are strongly anisotropic and may generate shear-wave splitting in the lower crust. Considering the wavelength of a teleseismic shear wave such as an SKS wave, the crust may contribute to the total splitting if the crustal anisotropy appears at a similar scale. Thus, one may expect a crustal contribution to the teleseismic shear-wave splitting if the crustal composition and structure are homogeneous enough at a large scale. From the calculated average samples, the birefringence displays some pervasive features: high birefringences for waves propagating parallel to the foliation and weak birefringences for waves propagating at high angle to the foliation. The regional structure of the study area has furthermore a regionally nearly constant orientation. The present-day layering is generally oriented NE-SW and is steeply dipping. In a seismic shear-wave experiment recording crustal splitting of vertically propagating shear waves, one can expect to measure fast split shear waves oriented NE-SW (i.e. parallel to the regional foliation and particularly to the kinzigite foliation). The magnitude of the delay time is more difficult to predict because it depends on the thickness of the anisotropic layer and on the magnitude of its anisotropy. For a seismic ray propagating in a given direction, the S-wave anisotropy is controlled by the composition of the medium but also by the orientation of the layering (Barruol and Mainprice, 1993a). The laboratory data and the seismic properties of the hypothetical mean rock calculated above may give some quantitative constraints and a reasonable upper and lower bound for the delay time. A maximum delay may be obtained by considering the kinzigite sample VS57. We calculated delay times of about $0.3 \mathrm{~s}$ for waves propagating parallel to the foliation through a $10 \mathrm{~km}$ thick layer with this composition. This value may be considered as an upper bound for the delay time because the rock is strongly anisotropic and because the calculations do not take into account several factors that would be included in a real field seismic experiment using longer wavelengths, such as lithological heterogeneities, fractures of the upper crust and variation of structural orientations. These three factors will almost systematically reduce the delay time except if microcracks are oriented parallel to the regional foliation. A second calculation has been done using the seismic properties of the average crustal sample. The calculated delay times are in this case about $0.1 \mathrm{~s}$ per $10 \mathrm{~km}$ of rock. Given the method by which the seismic properties were obtained, one may assume this calculation takes into account important compositional heterogeneities and that this delay time may represent a more realistic lower bound.

\section{Conclusions}

We investigated the seismic properties, particularly the shear-wave birefringence, of lower-crustal rocks by combining two different methods: (1) laboratory seismic measurements at various pressures and temperatures; (2) velocity calculations, based on modal composition, LPOs of major minerals, and single crystal stiffness coefficients and densities. Both methods were applied to four samples.

The measured seismic velocities, particularly of $P$ waves, are typical of those of the lower crust. In numerous samples, significant velocity anisotropy is evident, and shear waves generally display strong splitting parallel to the foliation. At normal incidence to the foliation, shear-wave splitting is practically absent. The laboratory-derived and calculated velocities are in good qualitative and quantitative agreement. We discussed the basic effects that may explain the discrepancies, such as rock composition, density, microfracturing, accuracy of the LPO and the basic assumptions used in the calculations.

To make a link between direct velocity measurements performed on hand specimens and large-scale seismology, we determined the elastic properties of 
hypothetical samples, which we consider to be more representative of large-scale lithological units. The calculated mean properties of the Ivrea Zone lower crust display important characteristics of hexagonal symmetry. The biotite and hornblende fabrics and the single crystal properties of these minerals clearly control the anisotropy and the S-wave splitting in the lower crust.

From our birefringence measurements performed on lower-crustal samples and assuming the anisotropy is mainly controlled by the rock fabric, we predict fast crustal split shear waves oriented NE-SW in a field seismic experiment, i.e. parallel to the presentday regional banding in the Ivrea Zone. Some simple calculations on the amplitude of the delay time leads us to predict high values, of around $0.1 \mathrm{~s}$ per $10 \mathrm{~km}$ of anisotropic layer.

\section{Acknowledgements}

We appreciate the help of $\mathrm{M}$. Schroetel in performing the experiments. H.K. is grateful to the Deutsche Forschungsgemeinschaft; G.B. thanks the Accompagnement ECORS 91/92 Programme and the DBT programme Thème Géodynamique for financial support, and also the Camegie Institution of Washington, Department of Terrestrial Magnetism and Geophysical Laboratory, in which part of this work has been done. This manuscript benefited from constructive reviews by N. Christensen and E. Rutter, and comments by R. Russo and A. Vauchez.

\section{References}

Aleksandrov, K.S. and Ryzhova, T.V., 1961. The elastic properties of rock forming minerals II: Layered silicates. Izv. Acad. Sci. USSR, Geophys. Ser., 12: 1799-1804 (in Russian).

Aleksandrov, K.S., Alchikov, U.V., Belikov, B.P., Zaslavskii, B.I. and Krupnyi, A.I., 1974. Velocities of elastic waves in minerals at atmospheric pressure and increasing precision of elastic constants by means of EVM (in Russian). Izv. Acad. Sci. USSR, Geol. Ser., 10: 15-24.

Baker, D.W. and Carter, N.L., 1972. Seismic velocity anisotropy calculated for ultramafic minerals and aggregates. Geophys. Monogr. Am. Geophys. Union, 16: 157-166.

Barruol, G. and Mainprice, D., 1993a. A quantitative evaluation of the contribution of crustal rocks to the shear wave splitting of teleseismic SKS waves. Phys. Earth Planet. Inter.. 78: 281300 .
Barruol, G. and Mainprice, D., 1993b. 3D seismic velocities calculated from LPOs and reflectivity of a lower crustal section-example of the Val Sesia (Ivrea Zone, Northern Italy). Geophys. J. Int., 115: 1169-1188.

Berckemer, H., 1968. Topographie des 'Ivrea körper' abgeleitet aus seismichen und gravimetrischen Daten. Schweiz. Mineral. Petrogr. Mitt., 48: 235-284.

Boriani, A., Burlini, L. and Sacchi, R., 1990. The CossatoMergozzo-Brissago line and the Pogallo line (Southem Alps, Northem Italy) and their relationships with the late Hercynian magmatic and metamorphic processes. Tectonophysics, 182: $91-102$.

Bormann, P., Burghardt, P.T., Makeyeva, L.I. and Vinnik, L.P., 1992. Teleseismic shear-wave splitting and deformations in central Europe. Phys. Earth Planet. Inter., 78: 157-166.

Boudier, F., Jackson, M. and Nicolas, A., 1984. Structural study of the Balmuccia massif (westem Alps): a transition from mantle to lower crust. Geol. Mijnbouw, 16: 179-188.

Brodie, K.H. and Rutter, E.H., 1987. Deep crustal extensional faulting in the Ivrea Zone of northem Italy. Tectonophysics, 140: $93-212$.

Burke, M.M. and Fountain, D.M., 1990. Seismic properties of rocks exposure of extended continental crust-new laboratory measurements from the Ivrea zone. Tectonophysics, 182: 119146.

Burlini, L., 1994. A model for the calculation of seismic properties of geologic units. Surv. Geophys., 15: 593-617.

Burlini, L. and Fountain, D.M., 1993. Seismic anisotropy of metapelites from the Ivrea-Verbano zone and Serie dei Laghi (N. Italy). Phys. Earth Planet. Inter., 78: 301-317.

Christensen, N.I., 1966. Shear wave velocities in metamorphic rocks at pressures to 10kilobars. J. Geophys. Res., 71: 35493556.

Christensen, N.I. and Crosson, R.S., 1968. Seismic anisotropy in the upper mantle. Tectonophysics, 6: 93-107.

Clement, W.P., Carbonell, R. and Smithson, S.B., 1994. Shearwave splitting in the lower crust beneath the Archean crust of southwest Greenland. Tectonophysics, 232: 195-210.

Crosson, R.S. and Lin, J.W., 1971. Voigt and Reuss prediction of anisotropic elasticity of dunite. J. Geophys. Res., 76: 570-578.

Fountain, D.M., 1976. The Ivrea-Verbano and Strona-Ceneri Zones, northem Italy: a cross-section of the continental crust -new evidence from seismic velocities of rock samples. Tectonophysics, 33: 145-165.

Gledhill, K.R., 1991. Evidence for shallow and pervasive seismic anisotropy in the Wellington region, New Zealand. J. Geophys. Res., 96: 21503-21516.

Handy, M., 1987. The structure, age and kinematics of the Pogallo fault zone, southem Alps, northem Italy. Eclogae Geol. Helv., 3: $593-632$.

Hodges, K.V. and Fountain, D.M., 1984. Pogallo line, south Alps, northem Italy: an intermediate crustal level, low-angle normal fault? Geology, 12: 151-155.

Holliger, K. and Levander, A., 1994. Structure and seismic response of extended continental crust: stochastic analysis of the Strona-Ceneri and Ivrea zones, Italy. Geology, 22: 79-82.

Hurich, C.A. and Smithson, S.B., 1987. Compositional variation 
and the origin of deep crustal reflections. Earth Planet. Sci. Lett., 85: 416-426.

Ji, S. and Salisbury, M.H., 1993. Shear-wave velocities, anisotropy and splitting in high grade mylonites. Tectonophysics, 221: 453-473.

Kaneshima, S., Ando, M. and Kimura, S., 1988. Evidence from shear-wave splitting for the restriction of seismic anisotropy to the upper crust. Nature, 335: 627-629.

Kem, H., 1990. Laboratory seismic measurements: an aid in the interpretation of seismic field data. Terra Nova, 2: 617-628.

Kem, H. and Wenk, H.R., 1990. Fabric-related velocity anisotropy and shear wave splitting in rocks from Santa Rosa mylonite zone, California. J. Geophys. Res., 95: 11213-11223.

Kem, H., Schmidt, R. and Popp, T., 1991. The velocity and density structure of the $4000 \mathrm{~m}$ crustal segment at the KTB drilling site and their relationship to lithological and microstructural characteristics of the rocks: an experimental approach. Sci. Drilling, 2: 130-145.

Kumazawa, M. and Anderson, O.L., 1969. Elastic moduli, pressure derivatives and temperature derivatives of single crystal olivine and single crystal forsterite. J. Geophys. Res., 74: 5961-5980.

Lloyd, G.E., 1985. Review of instrumentation, techniques and applications of SEM in mineralogy. In: J.C. White (Editor), Application of Electron Microscopy in the Earth Sciences. Mineral. Assoc. Can. Short Course, Vol. 11. London, pp. $151-188$.

Mainprice, D., 1990. A FORTRAN program to calculate seismic anisotropy from the lattice preferred orientation of minerals. Comput. Geosci., 16: 385-393.

Mainprice, D. and Silver, P.G., 1993. An evaluation of the factors affecting shear wave splitting in the mantle from petrofabric measurements of mantle xenoliths. Phys. Earth Planet. Inter., 78: $257-280$.

Mainprice, D. and Humbert, M., 1994. Methods of calculating petrophysical properties from lattice preferred orientation data. Surv. Geophys., 15: 575-592.

McNamara, D.E. and Owens, T.J., 1993. Azimuthal shear wave velocity anisotropy in the Basin and Range province using Moho Ps converted phases. J. Geophys. Res., 98: 1200312017.

Nye, J.F., 1972. Physical properties of crystals their representation by tensors and matrices. Oxford University Press, Oxford, 329 pp.

Peacock, S., Crampin, S., Booth, C. and Fletcher, J.B., 1988. Shear wave splitting in the Anza seismic gap, southem California: temporal variations as possible precursors. J. Geophys. Res., 93: 3339-3356.

Peselnick, L., Nicolas, A. and Stevenson, P.R., 1974. Velocity anisotropy in a mantle peridotite from the Ivrea Zone: application to upper mantle anisotropy. J. Geophys. Res., 79: 11751182.
Pin, C. and Sills, J.D., 1986. Petrogenesis of layered gabbros and ultramafic rocks from Val Sesia, NW Italy: trace elements and isotope geochemistry. In: J.B. Dawson, D.A. Carswell, J. Hall and K.H. Wedepohl (Editors), The Nature of the Continental Crust, Vol. 24. Geol. Soc. Spec. Publ., pp. 231-249.

Quick, J.E., Sinigoi, S., Negrini, L., Demarchi, G. and Mayer, A., 1992. Synmagmatic deformation in the underplated igneous complex of the Ivrea-Verbano zone. Geology, 20: 613-616.

Rivalenti, G., Garutti, G., Rossi, A., Siena, F. and Sinigoi, S., 1981. Existence of different peridotite types and of a layered igneous complex in the Ivrea Zone of the westem Alps. J. Petrol., 22: 127-153.

Rutter, E.H., Brodie, K.H. and Evans, P., 1993. Structural geometry, lower crustal magmatic underplating and lithospheric stretching in the Ivrea-Verbano zone, Northern Italy. J. Struct. Geol., 15: 647-662.

Schmid, R., 1967. Zur Petrographie und Struktur der Zone IvreaVerbano Zwischen Valle d'Ossola und Val Grande (Prov. Novara, Italien). Schweiz. Mineral. Petrogr. Mitt., 47: 9351117.

Siegesmund, S. and Kruhl, J.H., 1991. The effect of plagioclase textures on velocity anisotropy and shear wave splitting at deeper crustal levels. Tectonophysics, 191: 147-154.

Siegesmund, S. and Vollbrecht, A., 1991. Complete seismic properties obtained from microcracks fabric and textures in an amphibolite from the Ivrea Zone, Western Alps, Italy. Techonophysics, 199: 13-24.

Siegesmund, S., Takeshita, T. and Kern, H., 1989. Anisotropy of $V \mathrm{p}$ and $V \mathrm{~s}$ in an amphibolite of the deeper crust and its relationship to the mineralogical, microstructural and textural characteristics of the rock. Tectonophysics, 157: 25-38.

Sills, J.D. and Tamey, J., 1984. Petrogenesis and tectonic significance of amphibolites interlayered with metasedimentary gneisses in the Ivrea Zone, southern Alps, northwest Italy. Tectonophysics, 107: 187-206.

Silver, P.G. and Chan, W.W., 1991. Shear wave splitting and subcontinental mantle deformation. J. Geophys. Res., 96: 16429-16454.

Vaughan, M.T. and Guggenheim, S., 1986. Elasticity of muscovite and its relationship to crystal structure. J. Geophys. Res., 91: 4657-4664.

Weidner, D.J., Wang, H. and Ito, J., 1978. Elasticity of orthoenstatite. Phys. Earth Planet. Inter., 17: 7-13.

Zingg, A., 1980. Regional metamorphism in the Ivrea Zone (Southem Alps, N. Italy): field and microscopic investigation. Schweiz. Mineral. Petrogr. Mitt., 60: 153-179.

Zingg, A., Handy, M.R., Hunziker, J.C. and Schmid, S.M., 1990. Tectonometamorphic history of the Ivrea zone and its relationship to the crustal evolution of the southem Alps. Tectonophysics, 182: 169-192. 